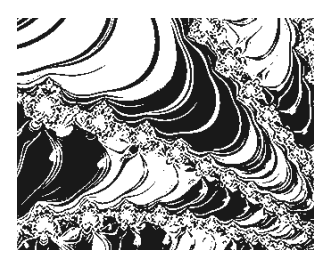

https://doi.org/10.5559/di.29.4.05

\title{
GOING THE EXTRA MILE: PERCEIVED SELF-EFFICACY, FAMILY-WORK ENRICHMENT, PROMOTION FOCUS, AND ORGANISATIONAL CITIZENSHIP BEHAVIOUR
}

Diellza GASHI TRESI

Riinvest College, Prishtinë, Kosovo

Katarina Katja MIHELIČ

University of Ljubliana, School of Economics and Business, Ljubliana, Slovenia

UDK: 005.32:316.663.5-057.16-058.833

Izvorni znanstveni rad

Primljeno: 5. 7. 2018.

Drawing on control theory, this paper moves closer to understanding the individual antecedents of employee citizenship behaviours. It explores the combined effect of three antecedents - job self-efficacy, family-work enrichment, and promotion focus - on service delivery organisational citizenship behaviour. Moderated Hierarchical Regression Modelling is performed on a sample of 198 call centre employees. The findings show a U-shaped curvilinear relationship between job self-efficacy and service delivery organisational citizenship behaviour for those employees who experience family-work enrichment. The results also confirm the three-way interaction of job self-efficacy, family-work enrichment, and promotion focus as joint predictors of citizenship behaviour. Theoretical implications are outlined along with practical steps for employers motivated to encourage citizenship behaviours in their teams, departments and sectors.

Keywords: self-efficacy, family-work enrichment, promotion focus, organisational citizenship behaviour

Katarina Katja Mihelič, University of Ljubljana,

School of Economics and Business, Kardeljeva ploščad 17, 1000 Ljubliana, Slovenia.

E-mail: katja.mihelic@ef.uni-li.si 
When employees "go the extra mile" in organisations, they perform tasks not included in their job descriptions such as helping a colleague in a family crisis with a project or arranging a team-building activity for the department in the expectation that future team goals will be exceeded. Such role behaviours that may be regarded as 'extra' are dubbed Organisational citizenship behaviours (hereafter: OCBs) with interest in them surging ever since they were academically conceptualised (Podsakoff et al., 2016). OCB comprises an individual's voluntary commitment within an organisation that is not part of their predetermined responsibilities (Organ, 1997), such as taking on additional projects and participating in non-obligatory meetings.

Organisations benefit from employees performing beyond their job duties because OCB contributes to the overall effectiveness of teams and departments (Podsakoff et al., 2014), positively impacts innovation and adaptability (Walz \& Niehoff, 1996), decreases counterproductive behaviour (Dalal, 2005) and leads to enhanced productivity and thus potential profitability (Mohammad et al., 2011). Because not all employees are willing to go the extra mile, particularly in times of increased workload, it is important to understand the individual characteristics that facilitate OCB. Existing research, for example, finds that all the Big 5 factors of personality (i.e. conscientiousness, emotional stability, extraversion, openness and agreeableness) are positively associated with OCB (Chiaburu et al., 2011). Also, among work-family concepts, work-family enrichment is positively related to OCB (Jenkins et al., 2016) while work-family conflict exhibits a negative association (Cloninger et al., 2015).

Self-efficacy, the belief that an individual possesses the competencies they need to take control of life events (Bandura, 1997), also has a positive role in OCB (Morrison \& Phelps, 1999; Paramasivam, 2015; Shahidi et al., 2015). However, researchers contend that while some factors initially positively relate with individual behaviours, they can, after a certain time and intensity of influence, end up exhibiting a negative association (i.e. 'too much of a good thing effect') (Grant \& Schwartz, 2011). Self-efficacy is one such factor (Grant \& Schwartz, 2011), which creates feelings of overconfidence (Whyte, 1998) and ultimately may result in an employee doing a poorer job at work. Yet, this has not been empirically tested in relation to OCB. Furthermore, it is still unclear how self-efficacy interacts with self-regulatory and work-family variables in relation to OCB in organisations.

Based on the deliberations above, it is paramount to further test when individual antecedents facilitate high and low 
DRUŠ. ISTRAŽ. ZAGREB GOD. 29 (2020), BR. 4, STR. 599-619

GASHI TRESI, D., MIHELIČ, K. K. GOING THE EXTRA.. levels of OCB. Building on control theory (Powers, 1973), which holds that an employee's motivation to invest resources depends on their assessment of the current and anticipated states and goals (Vancouver \& Kendall, 2006), and by adopting a quantitative cross-sectional research design, this paper's aims are to test: 1 ) a curvilinear relationship between self-efficacy and OCB; and 2) the triple interaction of self-efficacy, family-work enrichment, and promotion focus and its relationship with employees' OCB in a service delivery context.

The specific combination of antecedents was chosen because they correspond with the preferences and characteristics of Millennials, currently the largest cohort in the workforce, who strive to develop and advance rapidly while still preferring work-life balance (Jenkins, 2018), are achievement-oriented (Ng et al., 2010) and self-confident (Zimmerman, 2018). Today's workplace characteristics and societal expectations, whereby everyone is motivated to push forward, mean that confidence is required, as reflected in high self-efficacy. Moreover, family-work enrichment, which refers to a process where participation in the family role increases the quality or performance in the role at work (Greenhaus \& Powell, 2006), show that work and private lives are inherently intertwined. Finally, promotion focus is a regulatory state concerned with an individual achieving the perfect version of oneself at work and being sensitive to the presence or absence of positive outcomes such as advancement, innovation and work accomplishments (Johnson et al., 2017). It is shown in an individual driven by development needs and growth.

This paper makes three main contributions to the literature. First, we intend to complement the self-efficacy literature by investigating the U-shaped relationship between self-efficacy and OCB. We thereby follow Grant and Schwartz (2011), who encourage investigating curvilinear relationships in positive phenomena. Second, we aim to contribute to a more nuanced understanding of the individual antecedents of OCB by testing the triple interaction of self-efficacy, family-work enrichment and promotion focus. This contribution is important as it points to the circumstances in which high self-efficacy can facilitate behaviours, valuable for the organisation. Moreover, it extends to prior work on family-work enrichment, an area considered to be relatively understudied (Mishra, 2015; Jain \& Nair, 2017), and shows organisations and employees that non-work roles play a role in service delivery OCB. Third, we will complement the relatively scant literature on service-oriented OCB. Namely, very few studies have focused on OCB in a service setting, especially in employees who deal with customers (Wang, 2009). This specific form of 
DRUŠ. ISTRAŽ. ZAGREB GOD. 29 (2020), BR. 4, STR. 599-619

GASHI TRESI, D., MIHELIČ, K. K.: GOING THE EXTRA...
OCB has been chosen because it analyses the voluntary effort made by an employee in seeking to ensure that they offer an excellent customer service. It differs from general OCB as it is externally, not internally, focused. It encompasses employees' voluntary commitment to offering a high quality and reliable service to a customer (Kao, 2017) and not to their colleagues or for their organisation. It is relevant to explore this context as the service industry is expanding rapidly (Wang, 2009). Moreover, ever greater competitiveness in the service industry means that employees who go the extra mile can make a vital difference.

\section{THEORETICAL BACKGROUND}

\section{Self-efficacy and organisational citizenship behaviour}

Self-efficacy, as an important predictor of individuals' thinking and acting, relates to human behaviour and individual work performance $^{1}$ (Prieto, 2009). Job self-efficacy refers to the beliefs an individual holds about their ability to successfully accomplish tasks at work (Spreitzer, 1995). To date, most studies assumed a positive linear relationship between self-efficacy and OCB. For example, among faculty members self-efficacy is linearly related to OCB (Shahidi et al., 2015), and white collar employees with high self-efficacy are more prone to taking charge of actions which can lead to them exhibiting OCB (Morrison \& Phelps, 1999). Self-efficacy of engineering college teachers in India was positively related to OCB (Paramasivam, 2015).

While a direct negative association between self-efficacy and OCB has so far not been established, existing studies in related areas give indication that it may exist. For example, Vancouver and Kendall (2006) demonstrated that employed students with high self-efficacy tend to be overconfident and exhibit negative academic performance. Individuals with high self-efficacy beliefs and who think of a task as being easy to deal with invest less effort (Salomon, 1984) and do not persist in a task (Whyte et al., 1997).

Gleaning from the above negative effects of self-efficacy, we propose the relationship between self-efficacy and OCB is curvilinear rather than linear, meaning that heightened levels of self-efficacy can actually be positive up to a certain point and then relate negatively to OCB. We build this assumption on control theory (Powers, 1973), which foresees a negative relationship between self-efficacy and individual performance (Vancouver \& Kendall, 2006). According to the theory, individuals aspire to reduce the discrepancy between the desired level of performance and perception of performance (i.e. 
DRUŠ. ISTRAŽ. ZAGREB GOD. 29 (2020), BR. 4, STR. 599-619

GASHI TRESI, D., MIHELIČ, K. K.: GOING THE EXTRA.. preparedness for a task) (Powers, 1973). Individuals also make judgements as to whether the discrepancy between the desired performance and preparedness for a task is high or low (Koriat, 1997). Self-efficacy comprises individuals' judgements and beliefs in their abilities to accomplish a given task (Vancouver \& Kendall, 2006).

Vancouver and Kendall (2006, p. 1147) observe that "when self-efficacy beliefs are relatively high, individuals could be expected to devote fewer resources (e.g., study less) because their discrepancy is smaller compared with when their self-efficacy is relatively low". Following their observation, we expect in our context that when an employee's self-efficacy is very high, the employee will invest fewer resources and engage less in OCB as the particular employee will feel that all customers' claims are easy to handle. Employees with high self-efficacy may not take into account the risks involved in exhibiting certain behaviours, or may, because of their belief in their skills and their overconfidence (Whyte, 1998), invest little time in preparation. In practice, this means that employees may decrease their assistance to clients, come up with fewer ideas on how to solve a problem, not take into account how colleagues have approached similar issues recently due to poor learning and lack of preparation (Vancouver \& Kendall, 2006), and not consider alternative scenarios and solutions.

We argue that employees will engage in service delivery OCB (i.e. treating customers with respect and professionally approaching the request, regardless of the circumstances and responding to complaints in less time than required) up to a point after which they will, due to high self-efficacy, start feeling overconfident, assume that they know how to handle all customers' claims without preparation and always offer the best solution, which will result in poorer citizenship behaviours.

H1: There will be an inverted U-shaped relationship between job self-efficacy and service delivery organisational citizenship behaviour.

\section{The interplay of self-efficacy, promotion focus, and family-work enrichment in predicting organisational citizenship behaviour}

We propose that particular variables can interact with self-efficacy to facilitate service delivery OCB (see Figure 1). Specifically, we propose two different conditions: high levels of self-efficacy, promotion focus, and family-work enrichment are related with highest levels of OCB; conversely, low levels of self-efficacy, promotion focus and family-work enrichment are related to lowest levels of OCB. In line with control theo- 
DRUŠ. ISTRAŽ. ZAGREB GOD. 29 (2020), BR. 4, STR. 599-619

GASHI TRESI, D., MIHELIČ, K. K.: GOING THE EXTRA... ry (Powers, 1973), the first interacting variable is regulatory focus. Promotion-focused employees tend to pursue beneficial outcomes at work via OCB (Lanaj et al., 2012). This enables them to reach their goals relating to rewards, promotion and personal growth within the organisation (Lanaj et al., 2012).

However, solely being promotion-focused might not be enough for an employee with high self-efficacy to engage in voluntary behaviours, because high-achieving employees might feel strained by additional work such as helping colleagues or customers (Loeb, 2016). They might hold back from engaging in these and other kinds of OCB because of their exclusive focus on their own work goals and needs without taking others into consideration. That said, there is a need for a second supporting variable that will drive an employee with high self-efficacy and high promotion focus to pursue voluntary behaviours. We conceptualise family-work enrichment as such a variable, high levels of which can energise high-achieving employees and help alleviate the burden of strain and overload resulting from extra-role behaviours at work such as helping colleagues or customers. When the three interacting variables exist at high levels, OCB is expected to reach its highest levels. Conversely, when the three interacting variables are at low levels, the resulting OCB will be at its lowest level. In what follows, we present the argumentation for both conditions.

When employees have high levels of promotion focus, self-efficacy will also be high as those employees who are promotion-focused believe in their ability to carry out activities required to achieve tasks and goals at work (Higgins, 1997). This corresponds with control theory (Powers, 1973): agreeing to take on a challenging goal may result in a positive self-efficacy-individual performance link (Vancouver et al., 2001). Highly promotion-focused employees have higher self-efficacy possibly because they perceive difficult tasks as challenges that ought to be dealt with rather than avoided (Carmona et al., 2008). Along the same lines, those employees who view job demands as challenge stressors, rather than as hindrance stressors, exhibit higher levels of work engagement (Crawford et al., 2010), as challenges are evaluated as on-the-job demands that enable an employee to achieve future gains (Crawford et al., 2010). Still, some job demands might always be perceived as hindrances and never as challenge stressors and even lead to burnout (Crawford et al., 2010). Related to our case, challenge and hindrance stressors have been shown to be linked in opposing directions with performance and job attitudes (LePine et al., 2005).

In contrast, employees with low levels of promotion focus tend to be more careful at work, and play on safe ground 
DRUŠ. ISTRAŽ. ZAGREB GOD. 29 (2020), BR. 4, STR. 599-619

GASHI TRESI, D., MIHELIČ, K. K.: GOING THE EXTRA... so that they are accurate (Higgins, 1997), and as such might hesitate to engage in OCB since their focus might be on maintaining what they already have achieved and preventing negative outcomes at work (Higgins, 1997). Therefore, employees who are low in self-efficacy and low in promotion focus will focus on doing only what is required from them and demonstrate low levels of OCB.

To engage in OCB, employees with high self-efficacy and high promotion-focus would also need to enrich work through a positive family experience in order to demonstrate high OCB. Jenkins et al. (2016, p. 130) even suggested that "OCBs may be a behavioral outcome of family-work enrichment". We argue that employees whose family role has a synergistic effect on their work role will engage more at work. The extra resource gained in the family domain (e.g. energy, skills, positive affect) (Carlson et al., 2006) will enhance employees working above and beyond their official duties. In support of this assertion, employees who experience high levels of family-work enrichment benefit from the positive feelings produced at home in the form of stronger beliefs in their ability to accomplish work tasks (Chan et al., 2016). In addition, social support from family and a Significant Other both increase the perceived ability to complete a job at work (Schwarzer \& Knoll, 2007) and engage in OCB (Jakopec \& Sušanj, 2014).

In our context, satisfaction gained in the family role can buffer employees from stress arising from the work role. People whose family role accounts for their well-being may be less affected by the strain created by the higher level of service they provide to clients. Ruderman et al. (2002) give support for this argument by finding that being engaged in one's family role made people more patient in their work role. It may thus be assumed that employees who experience and learn in their family role may be more attentive to clients, actively listen and search for the best possible solutions and less strained due to energy reserves accumulated in the family role.

Conversely, employees who do not find support from their family in the form of family-work enrichment will not develop resources from their family role (e.g. energy, problem-solving skills) (Carlson et al., 2006; Chan et al., 2016) which, in turn, could undermine their confidence in their ability to complete work goals (Chan et al., 2016). The lack of such benefits might mean that employees do not have additional personal resources available for being engaged at work beyond official duties.

In sum, the presence of high levels of promotion focus and family-work enrichment will guide employees with high self-efficacy on how to invest their resources at work so that they end up providing a high-quality service to customers. In 
DRUŠ. ISTRAŽ. ZAGREB GOD. 29 (2020), BR. 4, STR. 599-619

GASHI TRESI, D., MIHELIČ, K. K.: GOING THE EXTRA... $\rightarrow$ FIGURE 1

Theoretical model addition, individuals who experience enrichment from the family role will transfer that into their work role resulting in positive outcomes (Greenhaus \& Powell, 2006), such as OCB. Further, family-work enrichment will help employees with greater promotion focus successfully manage their job demands which, in turn, will lead to more OCB through higher productivity (Wayne et al., 2004). Meanwhile, employees with low levels of self-efficacy, promotion focus and family-work enrichment will try to avoid negative consequences at work (Higgins, 1997). They will not benefit from positive experiences and emotions gained in their family role (Carlson et al., 2006; Chan et al., 2016) and not develop personal resources that help increase confidence in their ability to complete their work tasks (Chan et al., 2016). As such, they might hesitate to engage in OCB as they may feel they do not have 'what it takes' to successfully accomplish obligatory work tasks, thus making their engagement in voluntary behaviour minimal. Hence:

H2: The three-way interaction of job self-efficacy, promotion focus and family-work enrichment will predict service delivery OCB such that $2 a$ ) when promotion focus, family-work enrichment, and job self-efficacy are high, the level of service delivery OCB will be highest; $2 b$ ) when promotion focus, family-work enrichment, and job self-efficacy are low, service delivery OCB will be lowest.

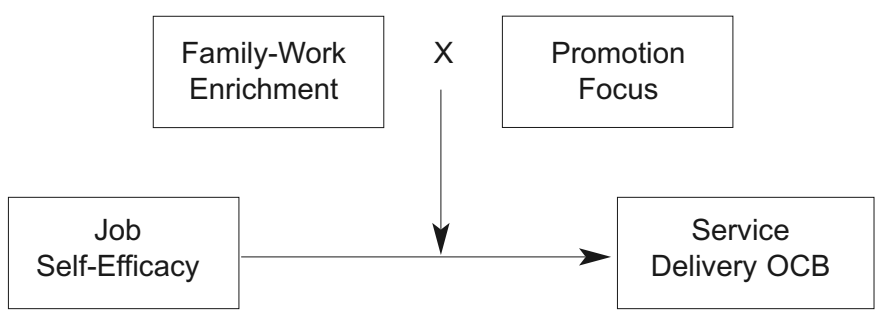

\section{METHODS}

\section{Sample and procedures}

Employees working at a call centre operating in Kosovo participated in this study. Call centres in Kosovo provide outsource solutions for companies based in Germany, Switzerland, the UK and the USA. Data were gathered via an electronic survey. An email was sent to 543 employees via the Human Resource Department explaining the reason for the survey. Participants were informed about the study's purpose and anonymity was assured. Participation in the study was voluntary and em- 
DRUŠ. ISTRAŽ. ZAGREB GOD. 29 (2020), BR. 4, STR. 599-619

GASHI TRESI, D. MIHELIČ, K. K.: GOING THE EXTRA... ployees were not offered any rewards. The questionnaire was translated into the Albanian language following Brislin's (1970) back-translation procedure. Exactly 211 employees responded to the survey (a 38\% response rate). Thirteen questionnaires were removed from further analysis due to missing values. Out of the remaining 198 respondents, 52\% were female and $48 \%$ were male. The respondents' mean age in years was 31.31 $(S D=7.91)$.

\section{Measures}

\section{Analytical procedure}

In terms of analysis, we began with a series of confirmatory factor analyses (CFA) and proceeded with moderated hierarchical regression analysis. To address potential concerns with common method variance, we conducted Harman's test which 
DRUŠ. ISTRAŽ. ZAGREB GOD. 29 (2020), BR. 4, STR. 599-619

GASHI TRESI, D., MIHELIČ, K. K.: GOING THE EXTRA... around $30.3 \%$ of variance. Thus, since the variance explained does not exceed the majority (50\% or more), there is little concern with respect to common method variance. We also calculated a marker variable test (see Simmering et al., 2015), which showed that common method variance was 0.053 , which is acceptable. Finally, it has been suggested that common method bias should not be a concern when testing interactions as it does not create an artificial interaction effect (Siemsen et al., 2010).

\section{RESULTS}

() TABLE 1

Descriptives, Correlations and Reliabilities
Table 1 provides descriptive statistics, correlations, and reliability coefficients. Cronbach's alpha coefficient ranges from 0.78 to 0.89 , showing that all measurement scales are internally consistent (Hair et al., 2014). As seen in Table 1, respondents report relatively high levels of service delivery OCB (mean $=6.11$, $S D=0.73)$.

\begin{tabular}{|c|c|c|c|c|c|c|c|c|c|c|c|c|}
\hline Variable & Mean & $S D$ & 1 & 2 & 3 & 4 & 5 & 6 & 7 & 8 & 9 & 10 \\
\hline 1 Service & & & & & & & & & & & & \\
\hline delivery OCB & 6.11 & 0.73 & $(0.78)$ & & & & & & & & & \\
\hline 2 Job self-efficacy & 6.28 & 0.72 & $0.44^{* *}$ & *(0.85) & & & & & & & & \\
\hline 3 Family-work & & & & & & & & & & & & \\
\hline enrichment & 5.30 & 1.0 & $0.35^{* *}$ & * $0.24^{* *}$ & *(0.89) & & & & & & & \\
\hline 4 Promotion focus & 5.80 & 0.80 & $0.43^{* *}$ & * $0.41^{* *}$ & * $0.42^{* *}$ & *(0.83) & & & & & & \\
\hline 5 Gender & 1.52 & 0.50 & $0.24^{* *}$ & * 0.00 & $0.18^{*}$ & $0.21^{* *}$ & * - & & & & & \\
\hline 6 Age & 31.31 & 7.91 & $0.17^{*}$ & 0.05 & -0.09 & -0.02 & 0.06 & - & & & & \\
\hline 7 Education & 2.23 & 0.73 & 0.02 & $0.21^{* *}$ & * 0.04 & $0.17^{*}$ & $0.16^{*}$ & $0.20^{* *}$ & - & & & \\
\hline $\begin{array}{l}8 \text { Years working } \\
\text { in the company }\end{array}$ & 5.41 & 5.06 & 0.13 & 0.11 & -0.08 & -0.01 & 0.00 & $0.57^{* *}$ & $0.17^{*}$ & - & & \\
\hline $\begin{array}{l}9 \text { Hours of work } \\
\text { per week }\end{array}$ & 39.96 & 12.83 & -0.06 & 0.00 & -0.08 & $-0.16^{*}$ & -0.09 & $0.23^{* *}$ & 0.07 & 0.10 & - & \\
\hline 10 Marital status & 1.64 & 0.73 & $0.17^{*}$ & 0.09 & 0.02 & -0.02 & 0.05 & $0.41^{* *}$ & $0.18^{* *}$ & $0.30^{* *}$ & 0.11 & - \\
\hline $\begin{array}{l}11 \text { No. of children } \\
\text { under } 6 \text { years }\end{array}$ & 0.39 & 0.63 & -0.1 & -0.05 & -0.08 & -0.07 & -0.07 & $0.21^{* *}$ & 0.13 & $0.26^{* *}$ & $0.16^{*}$ & $0.32^{* *}-$ \\
\hline
\end{tabular}

Notes: $n=198$. OCB - organisational citizenship behaviour. The coefficient $\alpha$-s are on the diagonal in parentheses. For gender, 1 = "male", 2 = "female"; For marital status: 1 - Single, 2 - Married, 3 - Divorced/ Separated, 4 - Living with partner, 5 - Widowed; For education: 1 - high school, 2 - bachelor degree, 3 - master degree, 4 - doctorate. ${ }^{*} p<0.05 ;{ }^{* *} p<0.01$

Before testing the proposed hypotheses, we evaluated the factor structure for the four constructs. The proposed structure fit the data well: $\chi^{2}[241]=389.50, \mathrm{CFI}=0.94, \mathrm{TLI}=0.93$, $\mathrm{SRMR}=0.059, \mathrm{RMSEA}=0.056$. All item loadings were statistically significant. We tested alternative models to assess discriminant validity and the results showed a worse fit with the data (job self-efficacy and service delivery OCB items on the same factor: $\chi^{2}[244]=544.596, \mathrm{CFI}=0.884$, TLI $=0.868$, SRMR $=$ 0.0833 , RMSEA $=0.079$; FWE and promotion focus items on 
DRUŠ. ISTRAŽ. ZAGREB GOD. 29 (2020), BR. 4, STR. 599-619

GASHI TRESI, D., MIHELIČ, K. K.: GOING THE EXTRA.. the same factor: $\chi^{2}[248]=1145.928, \mathrm{CFI}=0.625$, TLI $=0.613$, SRMR $=0.115$, RMSEA $=0.136)$. We thereby demonstrated the discriminant validity.

To test the hypotheses, we used a moderated hierarchical regression analysis (see Table 2). As per Aiken \& West (1991), we grand-mean-centred the three independent variables before testing in order to avoid multicollinearity between the linear term and quadratic term. In Model 1, we entered the control variables. In Model 2, we included all linear effects of the three independent variables, job self-efficacy, family-work enrichment, and promotion focus. In Model 3, we included the quadratic term of job self-efficacy. As per Table 2, the coefficient associated with this term was negative but statistically non-significant $(\beta=-0.03, p=0.683$ ), thus we cannot find support for H1. In Model 4, we entered all two-way interactions and the only marginally significant interaction was that between job self-efficacy squared and family-work enrichment $(\beta=0.18, p=0.079)$, thus showing that the relationship between job self-efficacy and service delivery OCB is U-shaped rather than U-inverted for employees who experience family-work enrichment.

In order to test $\mathrm{H} 2 \mathrm{a}$ and $\mathrm{H} 2 \mathrm{~b}$, we multiplied the centred values of the three independent variables and entered the values in Model 5. The linear three-way interaction effect was significant $(\beta=0.28, p=0.011)$ and the squared three-way interaction effect was marginally significant $(\beta=0.27, p=0.087)$. We used changes in $R^{2}$ to evaluate how the interaction terms explain the variance beyond that accounted for by the main effects in the equation (see Table 2), and the results demonstrated that the full model explained the additional variance. The results give support to $\mathrm{H} 2 \mathrm{a}$ and $\mathrm{H} 2 \mathrm{~b}$. The conditions are depicted in Figure 2 and Figure 3, where we plot the effects at one standard deviation above and below the mean of the moderating variables - family-work enrichment and promotion focus. These two figures show that when promotion focus, family-work enrichment, and job self-efficacy are high, the resulting OCB will be highest. In contrast, when promotion focus, family-work enrichment, and job self-efficacy are low, the resulting OCB will be lowest. In the post hoc analysis using Process Macro for SPSS (Hayes, 2018), we extracted asymmetric bias-corrected bootstrap confidence intervals to make inferences about the interaction effects using 5,000 bootstrap samples. The $95 \%$ bootstrap confidence interval for the interaction effect is significantly different from zero among all except those which have low family-work enrichment and high promotion focus, or the other way around. 


\begin{tabular}{|c|c|c|c|c|c|c|}
\hline & & Model 1 & Model 2 & Model 3 & Model 4 & Model 5 \\
\hline \multicolumn{2}{|l|}{ Intercept } & $5.33(0.30)^{* * *}$ & $5.58(0.26)^{* * *}$ & $5.59(0.26)^{* * *}$ & $5.71(0.26)^{* * *}$ & $5.78(0.26)^{* * *}$ \\
\hline \multicolumn{2}{|l|}{ Gender } & $0.22(0.10)^{* *}$ & $0.16(0.09)^{* *}$ & $0.16(0.09)^{* *}$ & $0.15(0.09)^{*}$ & $0.14(0.09)^{*}$ \\
\hline \multicolumn{2}{|l|}{ Age } & $0.11(0.01)$ & $0.16(0.01)^{*}$ & $0.16(0.01)^{*}$ & $0.16(0.01)^{*}$ & $0.18(0.01)^{*}$ \\
\hline \multicolumn{2}{|l|}{ Education } & $-0.05(0.07)$ & $-0.17(0.06)^{* *}$ & $-0.17(0.06)^{* *}$ & $-0.17(0.06)^{* *}$ & $-0.19(0.06)^{* *}$ \\
\hline \multicolumn{2}{|c|}{ Years working in the company } & $0.07(0.01)$ & $0.03(0.01)$ & $0.03(0.01)$ & $0.01(0.01)$ & $0.01(0.01)$ \\
\hline \multicolumn{2}{|c|}{ Hours of work per week } & $-0.07(0.00)$ & $-0.03(0.00)$ & $-0.03(0.00)$ & $-0.06(0.00)$ & $-0.08(0.00)$ \\
\hline \multicolumn{2}{|l|}{ Marital status } & $0.14(0.08) \dagger$ & $0.10(0.07)$ & $0.10(0.07)$ & $0.11(0.07)$ & $0.11(0.07)$ \\
\hline \multicolumn{2}{|c|}{ No. of children under 6 years } & $-0.11(0.09)$ & $-0.06(0.07)$ & $-0.06(0.07)$ & $-0.08(0.08)$ & $-0.09(0.07)$ \\
\hline \multicolumn{2}{|l|}{ Job S.E. } & & $0.32(0.07)^{* * *}$ & $0.30(0.08)^{* * *}$ & $0.31(0.09)^{* * *}$ & $0.23(0.09)^{* *}$ \\
\hline \multicolumn{2}{|l|}{ FWE } & & $0.15(0.05)^{*}$ & $0.16(0.05)^{*}$ & $0.08(0.06)$ & $0.02(0.06)^{*}$ \\
\hline \multirow{2}{*}{\multicolumn{2}{|c|}{$\begin{array}{l}\text { Promotion focus } \\
\text { Job S.E. }{ }^{2}\end{array}$}} & & $0.24(0.06)^{* * *}$ & $0.24(0.06)^{* * *}$ & $0.23(0.07)^{* *}$ & $0.19(0.07)$ \\
\hline & & & & $-0.03(0.06)$ & $0.02(0.07)$ & $-0.03(0.07)$ \\
\hline \multirow{7}{*}{ Interaction effects } & \multicolumn{2}{|c|}{ Job S.E. x FWE } & & & $-0.01(0.09)$ & $0.00(0.09)$ \\
\hline & \multicolumn{2}{|c|}{ Job S.E. ${ }^{2} \times$ FWE } & & & $0.18(0.07) \dagger$ & $0.15(0.09)$ \\
\hline & \multicolumn{2}{|c|}{ Job S.E. $\times$ PF } & & & $-0.07(0.12)$ & $-0.03(0.12)$ \\
\hline & \multicolumn{2}{|c|}{ Job S.E. ${ }^{2} \times$ PF } & & & $-0.05(0.09)$ & $0.08(0.11)$ \\
\hline & \multirow{2}{*}{\multicolumn{2}{|c|}{$\begin{array}{l}\text { FWE } \times \text { PF } \\
\text { Job S.E } \times \text { FWE } \times \text { PF }\end{array}$}} & & & $-0.02(0.06)$ & $-0.06(0.06)$ \\
\hline & & & & & & $0.28(0.10)^{* *}$ \\
\hline & \multicolumn{2}{|c|}{ Job S.E. ${ }^{2}$ FWE x PF } & & & & $0.27(0.08) \dagger$ \\
\hline \multicolumn{2}{|l|}{ F } & $3.44^{* *}$ & $11.58^{* * *}$ & $10.50^{* * *}$ & $7.82^{* * *}$ & $7.66^{* * *}$ \\
\hline \multicolumn{2}{|l|}{$R$} & 0.34 & 0.62 & 0.62 & 0.64 & 0.66 \\
\hline \multicolumn{2}{|l|}{$R^{2}$} & $0.11^{* *}$ & $0.38^{* * *}$ & $0.38^{* * *}$ & $0.41^{* * *}$ & $0.44^{* * *}$ \\
\hline \multicolumn{2}{|l|}{$\Delta R^{2}$} & $0.11^{* *}$ & $0.27^{* * *}$ & 0.01 & $0.03^{*}$ & $0.03^{*}$ \\
\hline \multicolumn{2}{|l|}{ Adjusted $R^{2}$} & $0.08^{* *}$ & $0.35^{* * *}$ & 0.35 & $0.36^{*}$ & $0.38^{*}$ \\
\hline
\end{tabular}

Notes: $n=198$. S.E. - self-efficacy; FWE - family-work enrichment; PF - promotion focus. Standardised regression coefficients and estimations of standard errors are displayed. $t p \leq 0.10 ;{ }^{*} p<0.05 ;{ }^{* *} p<0.01$; ${ }^{* * *} p<0.001$

\begin{tabular}{lrrrrrrr}
\hline $\begin{array}{l}\text { Conditional effect of } X \text { on } Y \\
\text { at values of the moderators }\end{array}$ & FWE & PF & Effect & se & $p$ & LLCI & ULCI \\
& 4.30 & 5.00 & 0.5084 & 0.0905 & 0.0000 & 0.3590 & 0.6580 \\
& 4.30 & 5.80 & 0.3280 & 0.0980 & 0.0010 & 0.1660 & 0.4900 \\
& 4.30 & 6.60 & 0.1476 & 0.1558 & 0.3444 & -0.1098 & 0.4051 \\
& 5.30 & 5.00 & 0.2836 & 0.1014 & 0.0057 & 0.1160 & 0.4512 \\
& 5.30 & 5.80 & 0.2605 & 0.0684 & 0.0002 & 0.1475 & 0.3735 \\
& 5.30 & 6.60 & 0.2374 & 0.1121 & 0.0356 & 0.0520 & 0.4227 \\
& 6.30 & 5.00 & 0.0587 & 0.1720 & 0.7331 & -0.2255 & 0.3430 \\
$\begin{array}{c}\text { R TABLE 2 } \\
\text { Results of moderated } \\
\text { hierarchical regression }\end{array}$ & 6.30 & 5.80 & 0.1929 & 0.1050 & 0.0676 & 0.0194 & 0.3664 \\
analyses & 6.30 & 6.60 & 0.3271 & 0.1614 & 0.0441 & 0.0603 & 0.5939 \\
\hline
\end{tabular}
analyses

Notes: FWE - family-work enrichment; PF - promotion focus

\section{$\Rightarrow$ FIGURE 2}

Three-way linear interaction of job self-efficacy, family-work enrichment, and promotion focus in predicting service delivery OCB

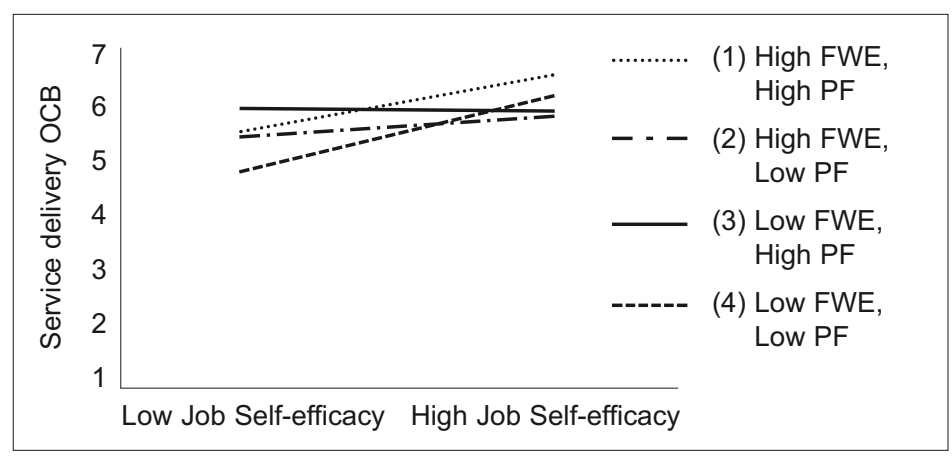

Notes: FWE - family-work enrichment; PF - promotion focus 
DRUŠ. ISTRAŽ. ZAGREB GOD. 29 (2020), BR. 4, STR. 599-619

GASHI TRESI, D. MIHELIČ, K. K.: GOING THE EXTRA...

FIGURE 3

Three-way curvilinear interaction of job self-efficacy, family-work enrichment, and promotion focus in predicting service delivery OCB

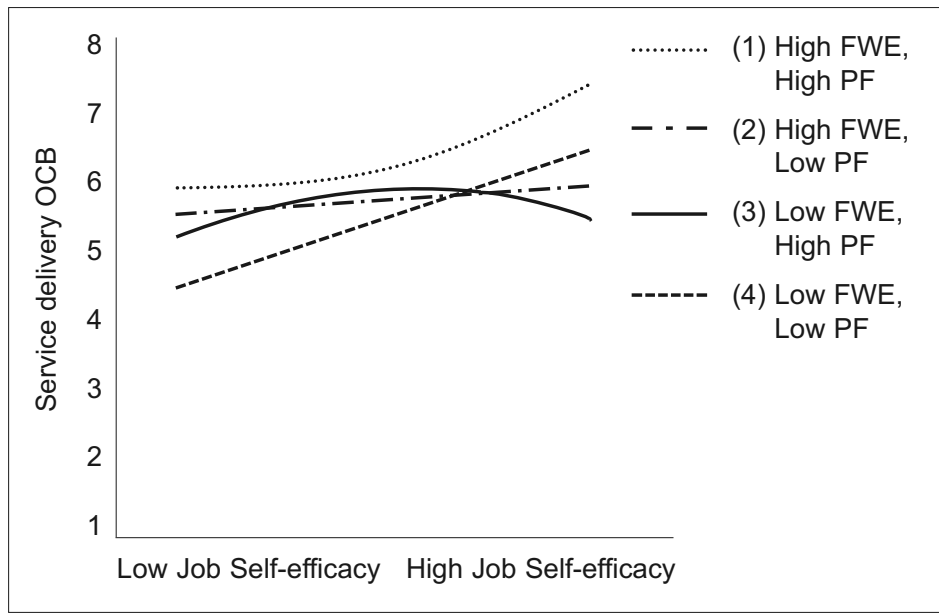

DISCUSSION

In this study, we did not find support for an inverted U-shaped relationship between job self-efficacy and service delivery OCB (H1). One reason for this result might be that an individual who chooses to accept a challenging goal, such as always striving to provide superior service to customers, really does make sure they do well in the workplace because their motivation increases (Vancouver et al., 2001). In our context, it might be that call centre employees who have set themselves the goal to diligently respond to customers' claims show high OCB due to increased motivation. Another reason might lie in the scale used to measure OCB. While other studies used scales that measured OCB directed to the organisation and/or OCB directed to the individual, we measured service delivery OCB (Bettencourt et al., 2001). However, we did demonstrate that the relationship between job self-efficacy and service delivery OCB followed a U-shaped function for employees who experience family-work enrichment.

Moreover, we found a three-way interaction. More specifically, the level of service delivery OCB is highest when job self-efficacy, family-work enrichment, and promotion focus are all high $(\mathrm{H} 2 \mathrm{a})$. Conversely, the level of service delivery OCB is the lowest when job self-efficacy, family-work enrichment, and promotion focus are all low $(\mathrm{H} 2 \mathrm{~b})$. The results reflect findings of related previous studies which found that cognitive/personal variables, self-regulatory variables and family-work variables can impact extra-role behaviours (Jenkins et al., 2016). However, we went one step further and revealed that the three variables at high levels interact together to reach highest OCB, while at low levels they facilitate lowest OCB. Furthermore, by finding that the two-way interactions 
are non-significant while the three-way interaction is statistically significant, we show that the interplay of the three variables we have proposed is required in order to reach high and low levels of OCB respectively.

\section{Theoretical contributions}

So far, to the best of our knowledge no paper has tested a curvilinear relationship between job self-efficacy and service delivery OCB. We attempted to demonstrate that too much self-efficacy is not good for going the extra mile, but we were unable to ascertain this. However, the results provide marginally significant support for a U-shaped relationship between job self-efficacy and service delivery OCB for employees who experience family-work enrichment.

In addition, we broaden the understanding of how self-efficacy, a work-family variable, and a self-regulatory variable interact to impact service delivery OCB. This contribution is important because it reveals to managers the conditions in which high self-efficacy can lead to high OCB and instances where low self-efficacy can lead to low OCB. Moreover, we contribute to the work-family literature by extending research on family-work enrichment, considered to be an understudied phenomenon (Jain \& Nair, 2017). This study is one of the first to show that family-work enrichment is linked to service delivery OCB.

Finally, very few studies have focused on service OCB (Wang, 2009), and these employed samples of nurses and hotel frontline employees, suggesting there is very limited empirical support regarding service quality OCB (Kelley \& Hoffman, 1997). It is relevant to focus on analysing OCB in a service setting as the services industry is expanding rapidly (Kelley \& Hoffman, 1997; Wang, 2009). Studying what impacts OCB in a service setting is also important since such organisations are all about service, and thus the way call centre agents provide services to customers is paramount to the effectiveness of their organisation.

\section{Practical implications}

The results of the paper offer various practical implications on how to elicit high OCB, which may be of interest to supervisors and team leaders. First, supervisors could motivate their employees to increase their self-efficacy beliefs through developing a coaching leadership style (Demerouti et al., 2016), role modelling and verbal persuasion or encouragement (Bandura, 1997; van den Heuvel et al., 2015). Employees themselves can increase their self-efficacy levels by observing someone else perform a particular task (i.e. vicarious learning), and per- 
DRUŠ. ISTRAŽ. ZAGREB GOD. 29 (2020), BR. 4, STR. 599-619

GASHI TRESI, D., MIHELIČ, K. K.: GOING THE EXTRA.. suading oneself that if others can do it, then they should be able to do it as well (Bandura, 1997).

Second, our study shows that employees who experience family-work enrichment and have high self-efficacy beliefs will engage in OCB. Therefore, organisations should encourage employees to schedule activities on time (e.g. use time management tools), protect family and work times and inform family members of the scheduled activities in order for them to be mentally prepared (Mishra, 2015). Another way to facilitate family-work enrichment is for organisations to establish ties with their employees' family members by inviting them to participate in celebratory events (Jain \& Nair, 2017).

Third, a self-regulatory state is also a relevant factor that helps facilitate citizenship behaviours. Therefore, organisations could design initiatives which help their employees be promotion-focused rather than prevention-focused. Such initiatives could include training for improving self-regulatory skills (Bryant, 2007) and workshops to detect emerging patterns of pertinent factors that help come up with innovative solutions to challenges (Corbett \& Hmieleski, 2007).

\section{Limitations and suggestions for future research}

This study has limitations that need to be addressed by further research. First, as the data were self-reported, they might be susceptible to common method bias. Aside from conducting various tests reported in the analytical procedure, we followed expert advice and adopted various measures including using scales with reverse-coded items and assuring respondents' anonymity (Podsakoff et al., 2003). Moreover, Carpente et al. (2014) provide evidence that supports the use of self-rated OCB. Second, the adopted research design is cross-sectional and our ability to make conclusions regarding causality is thus limited. In order to observe causality or to confirm the direction proposed in the model, future studies should employ longitudinal designs or conduct experiments to account for the temporal dynamics.

Third, the employed sample is relatively small. While power analysis results (slightly above 0.80 ) indicated that the sample size is adequate for this study (Hair et al., 2014), future research projects could employ larger samples from the same industry to test the strength of the relationships. Researchers could also collect data in other European countries to provide a better understanding of the prevalence of OCB in different national settings.

The fourth limitation relates to the generalisability of the findings. The data used for this study were namely restricted to call centre employees. Although the same pattern of results 
DRUŠ. ISTRAŽ. ZAGREB GOD. 29 (2020), BR. 4, STR. 599-619

GASHI TRESI, D., MIHELIČ, K. K.: GOING THE EXTRA... may be expected, replication studies are needed in order to generalise the findings. Accordingly, to confirm that the results can be generalised to other industries, larger samples could be drawn in future studies and the proposed relationships could be tested on frontline employees working in other industries such as hotels or banks.

While our study tested two conditions that are practically most relevant, it does not hypothesise other combinations of the chosen variables that contribute to OCB. To remedy this shortcoming, future research might further test the ideas developed in this study by hypothesising other conditions. This would further a more nuanced understanding of how these individual variables drive employees to go the extra mile.

\section{NOTES}

\section{REFERENCES}

Aiken, L. S., \& West, S. G. (1991). Multiple regression: Testing and interpreting interactions. Sage Publications, Inc.

Bandura, A. (1997). Self-efficacy: The exercise of control. Freeman.

Bettencourt, L. A., Gwinner, K. P., \& Meuter, M. L. (2001). A comparison of attitude, personality, and knowledge predictors of service-oriented organizational citizenship behaviors. Journal of Applied Psychology, 86(1), 29-41. https://doi.org/10.1037//0021-9010.86.1.29

Brislin, R. W. (1970). Back-translation for cross-cultural research. Journal of Cross-Cultural Psychology, 1, 185-216. https://doi.org/10.1177/135910 457000100301

Bryant, P. (2007). Self-regulation and decision heuristics in entrepreneurial opportunity evaluation and exploitation. Management Decision, 45(4), 732-748. https://doi.org/10.1108/00251740710746006

Carlson, D. S., Kacmar, K. M., Wayne, J. H., \& Grzywacz, J. G. (2006). Measuring the positive side of the work-family interface: Development and validation of a work-family enrichment scale. Journal of Vocational Behavior, 68(1), 131-164. https://doi.org/10.1016/j.jvb.2005.02.002 
DRUŠ. ISTRAŽ. ZAGREB GOD. 29 (2020), BR. 4, STR. 599-619

GASHI TRESI, D. MIHELIČ, K. K.: GOING THE EXTRA..
Carmona, C., Buunk, A. P., Dijkstra, A., \& Peiró, J. M. (2008). The relationship between goal orientation, social comparison responses, self-efficacy, and performance. European Psychologist, 13(3), 188-196. https://doi. org/10.1027/1016-9040.13.3.188

Carpenter, N. C., Berry, C. M., \& Houston, L. (2014). A meta-analytic comparison of self-reported and other-reported organizational citizenship behavior. Journal of Organizational Behavior, 35(4), 547-574. https://doi. org/10.1002/job.1909

Carpini, J. A., Parker, S. K., \& Griffin, M. A. (2017). A look back and a leap forward: A review and synthesis of the individual work performance literature. Academy of Management Annals, 11(2), 825-885. https:// doi.org/10.5465/annals.2015.0151

Chan, X. W., Kalliath, T., Brough, P., Siu, O., O'Driscoll, M. P., \& Timms, C. (2016). Work-family enrichment and satisfaction: The mediating role of self-efficacy and work-life balance. The International Journal of Human Resource Management, 27(15), 1755-1776. https://doi.org/10.1080/ 09585192.2015.1075574

Chiaburu, D. S., Oh, I.-S., Berry, C. M., Li, N., \& Gardner, R. G. (2011). The Five-Factor Model of personality traits and organizational citizenship behaviors: A meta-analysis. Journal of Applied Psychology, 96(6), 1140-1166. https://doi.org/10.1037/a0024004

Cloninger, P. A., Selvarajan, T. T., Singh, B., \& Huang, Sh. (2015). The mediating influence of work-family conflict and the moderating influence of gender on employee outcomes. The International Journal of Human Resource Management, 26(18), 2269-2287. https://doi.org/10.1080/ 09585192.2015.1004101

Corbett, A. C., \& Hmieleski, K. M. (2007). The conflicting cognitions of corporate entrepreneurs. Entrepreneurship Theory \& Practice, 31(1), 103-121. https://doi.org/10.1111/j.1540-6520.2007.00165.x

Crawford, E. R., LePine, J. A., \& Rich, B. L. (2010). Linking job demands and resources to employee engagement and burnout: A theoretical extension and meta-analytic test. Journal of Applied Psychology, 95(5), 834. https://doi.org/10.1037/a0019364

Dalal, R. S. (2005). A meta-analysis of the relationship between organizational citizenship behavior and counterproductive work behavior. Journal of Applied Psychology, 90(6), 1241-1255. https://doi.org/10.1037/ 0021-9010.90.6.1241

Demerouti, E., Sanzs-Vergel, A. I., Petrou, P., \& van den Heuvel, M. (2016). How work-self conflict/facilitation influences exhaustion and task performance: A three-wave study on the role of personal resources. Journal of Occupational Health Psychology, 21(4), 391-402. https://doi. org/10.1037/ocp0000022

Grant, A. M., \& Schwartz, B. (2011). Too much of a good thing: The challenge and opportunity of the inverted U. Perspectives on Psychological Science, 6(1), 61-76. https://doi.org/10.1177/1745691610393523

Greenhaus, J. H., \& Powell, G. N. (2006). When work and family are allies: A theory of work-family enrichment. Academy of Management Review, 31(1), 72-92. https://doi.org/10.2307/20159186 
DRUŠ. ISTRAŽ. ZAGREB GOD. 29 (2020), BR. 4, STR. 599-619

GASHI TRESI, D., MIHELIČ, K. K.: GOING THE EXTRA...
Hair, J. F., Black, W. C., Babin, J. B., \& Anderson, R. E. (2014). Multivariate data analysis. Pearson New International Edition. Pearson Education Limited.

Hayes, A. F. (2018). Introduction to mediation, moderation, and conditional process analysis: A regression-based approach. Guilford Press.

Higgins, E. T. (1997). Beyond pleasure and pain. American Psychologist, 52(12), 1280-1300. https://doi.org/10.1037/0003-066X.52.12.1280

Jain, S., \& Nair, S. K. (2017). Work support and family support as predictors of work-to-family enrichment and family-to-work enrichment. Global Business Review 18(5), 1307-1324. https://doi.org/10.1177/09721 50917710332

Jakopec, A., \& Sušanj, Z. (2014). Effects of (mis)alignment between supervisory and organizational justice. Društvena istraživanja, 23(4), 615-637. https://doi.org/10.5559/di.23.4.04

Jenkins, J. S., Heneghan, C. J., Bailey, S. F., \& Barber, L. K. (2016). The work-family interface as a mediator between job demands and employee behaviour. Stress and Health, 32(2), 128-137. https://doi.org/10. 1002/smi.2586

Jenkins, R. (2018, January 8). This is why millennials care so much about work-life balance. Inc. https://www.inc.com/ryan-jenkins/this-is-whatmillennials-value-most-in-a-job-why.html

Johnson, R. E., King, D. D., Lin, S-H., Scott, B. A., Jackson Walker, E. M., \& Wang, M. (2017). Regulatory focus trickle-down: How leader regulatory focus and behavior shape follower regulatory focus. Organizational Behavior and Human Decision Processes 140, 29-45. https://doi. org/10.1016/j.obhdp.2017.03.002

Kao, R. (2017). Task-oriented work characteristics, self-efficacy, and service-oriented organizational citizenship behavior: A cross-level analysis of the moderating effect of social work characteristics and collective efficacy. Personnel Review, 46(4), 718-739. https://doi.org/10. 1108/PR-08-2015-0234

Kelley, S. W., \& Hoffman, D. K. (1997). An investigation of positive affect, prosocial behaviors, and service quality. Journal of Retailing, 73(3), 407-427. https://doi.org/10.1016/S0022-4359(97)90025-7

Koriat, A. (1997). Monitoring one's own knowledge during study: A cue-utilization approach to judgments of learning. Journal of Experimental Psychology: General, 126(4), 349-370. https://doi.org/10.1037/00 96-3445.126.4.349

Lanaj, K., Chang, C. H. D., \& Johnson, R. E. (2012). Regulatory focus and work-related outcomes: A review and meta-analysis. Psychological Bulletin, 138(5), 998-1034. https://doi.org/10.1037/a0027723

LePine, J. A., Podsakoff, N. P., \& LePine, M. A. (2005). A meta-analytic test of the challenge stressor-hindrance stressor framework: An explanation for inconsistent relationships among stressors and performance. Academy of Management Journal, 48(5), 764-775. https://doi.org/ 10.5465/amj.2005.18803921

Lockwood P., Jordan, C. H., \& Kunda, Z. (2002). Motivation by positive or negative role models: Regulatory focus determines who will best inspire us. Journal of Personality and Social Psychology, 83(4), 854-864. https://doi.org/10.1037//0022-3514.83.4.854 
DRUŠ. ISTRAŽ. ZAGREB GOD. 29 (2020), BR. 4, STR. 599-619

GASHI TRESI, D., MIHELIČ, K. K. GOING THE EXTRA..
Loeb, C. (2016). Self-efficacy at work: Social, emotional, and cognitive dimensions. (Unpublished doctoral dissertation). Mälardalen University, Västerås, Sweden.

Mishra, P. (2015). A grounded theory study on family-to-work enrichment: Exploring links with family resources, community resources, work-role salience and psychological capital. South Asian Journal of Global Business Research, 4(1), 45-67. https://doi.org/10.1108/SAJGBR07-2014-0052

Mohammad, J., Habib, F. Q., \& Alias, M. A. (2011). Job satisfaction and organisational citizenship behaviour: An empirical study at higher learning institutions. Asian Academy of Management Journal, 16(2), 149-165.

Morrison, E. W., \& Phelps, C. C. (1999). Taking charge at work: Extrarole efforts to initiate workplace change. Academy of Management Journal, 42(4), 403-419. https://doi.org/10.2307/257011

Ng, E. S. W., Schweitzer, L., \& Lyons, S. (2010). New generation, great expectations: A field study of the millennial generation. Journal of Business and Psychology, 25(2), 281-292. https://doi.org/10.1007/s108 69-010-9159-4

Organ, D. W. (1997). Organizational citizenship behavior: It's construct clean-up time. Human Performance, 10(2), 85-97. https://doi.org/ 10.1207/s15327043hup1002_2

Paramasivam, G. M. (2015). Role of self-efficacy and family supportive organizational perceptions in teachers' organizational citizenship behaviour: A study on engineering college teachers in India. Asian Education and Development Studies, 4(4), 394-408. https://doi.org/10. 1108/AEDS-01-2015-0001

Podsakoff, N. P., Podsakoff, P. M., MacKenzie, S. B., Maynes, T. D., \& Spoelma, T. M. (2014). Consequences of unit-level organizational citizenship behaviors: A review and recommendations for future research. Journal of Organizational Behavior, 35(S1), S87-S119. https://doi.org/10. 1002/job.1911

Podsakoff, P., Mackenzie, S., \& Podsakoff, N. (2016). Organizational citizenship behavior: Introduction and overview of the handbook. In The Oxford handbook of organizational citizenship behavior. Oxford University Press.

Podsakoff, P. M., MacKenzie, S. B., Lee, J.-Y., \& Podsakoff, N. P. (2003). Common method biases in behavioral research: A critical review of the literature and recommended remedies. Journal of Applied Psychology, 88(5), 879-903. https://doi.org/10.1037/0021-9010.88.5.879

Powers, W. T. (1973). Behavior: The control of perception. Aldine.

Prieto, L. L. (2009). Exploring the power of self-efficacy at work: Some empirical studies from the cognitive perspective. (Unpublished doctoral dissertation). Universitat Jaume, Castelló de la Plana, Spain.

Ruderman, M. N., Ohlott, P. J., Panzer, K., \& King, S. N. (2002). Benefits of multiple roles for managerial women. Academy of Management Journal, 45(2), 369-386. https://doi.org/10.2307/3069352

Salomon, G. (1984). Television is "easy" and print is "tough": The differential investment of mental effort in learning as a function of perception and attributions. Journal of Educational Psychology, 76(4), 647-658. https://doi.org/10.1037/0022-0663.76.4.647 
DRUŠ. ISTRAŽ. ZAGREB GOD. 29 (2020), BR. 4, STR. 599-619

GASHI TRESI, D., MIHELIČ, K. K.: GOING THE EXTRA...
Schwarzer, R., \& Knoll, N. (2007). Functional roles of social support within the stress and coping process: A theoretical and empirical overview. International Journal of Psychology, 42(4), 243-252. https://doi.org/ 10.1080/00207590701396641

Shahidi, N., Shamsnia, S. A., \& Baezat, S. (2015). Studying the relationship between self-efficacy and organizational citizenship behavior (case study: Islamic Azad University - Zone 1). International Research Journal of Applied and Basic Sciences, 9(9), 1499-1503. http://www. irjabs.com/files_site/paperlist/r_2711_150731164323.pdf

Siemsen, E., Roth, A., \& Oliveira, P. (2010). Common method bias in regression models with linear, quadratic, and interaction effects. Organizational Research Methods, 13(3), 456-476. https://doi.org/10.1177/ 1094428109351241

Simmering, M. J., Fuller, C. M., Richardson, H. A., Ocal, Y., \& Atinc, G. M. (2015). Marker variable choice, reporting, and interpretation in the detection of common method variance - A review and demonstration. Organizational Research Methods, 18(3), 473-511. https://doi. org $/ 10.1177 / 1094428114560023$

Spreitzer, G. M. (1995). Psychological empowerment in the workplace: Dimensions, measurement, and validation. Academy of Management Journal, 38(5), 1442-1465. https://doi.org/10.2307/256865

van den Heuvel, M., Demerouti, E., \& Peeters, M. C. W. (2015). The job crafting intervention: Effects on job resources, self-efficacy, and affective well-being. Journal of Occupational and Organizational Psychology, 88(3), 511-532. https://doi.org/10.1111/joop.12128

Vancouver, J. B., \& Kendall, L. N. (2006). When self-efficacy negatively relates to motivation and performance in a learning context. Journal of Applied Psychology, 91(5), 1146-1153. https://doi.org/10.1037/ 0021-9010.91.5.1146

Vancouver, J. B., Thompson, C. M., \& Williams, A. A. (2001). The changing signs in the relationship among self-efficacy, personal goals, and performance. Journal of Applied Psychology, 86(4), 605-620. https://doi. org/10.1037//0021-9010.86.4.605

Walz, S., \& Niehoff, B. P. (1996). Organizational citizenship behaviors and their effect on organizational effectiveness in limited-menu restaurants. Paper presented at Academy of Management Meetings, Cincinnati, Ohio. https://doi.org/10.5465/ambpp.1996.4980770

Wang, M. (2009). Does organizational support promote citizenship in service settings? The moderating role of service climate. The Journal of Social Psychology, 149(6), 648-676. https://doi.org/10.1080/00224540 903347297

Wayne, J. H., Musisca, N., \& Fleeson, W. (2004). Considering the role of personality in the work-family experience: Relationships of the big five to work-family conflict and facilitation. Journal of Vocational Behavior, 1(64), 108-130. https://doi.org/10.1016/S0001-8791(03)00035-6

Whyte, G., Saks, A. M., \& Hook, S. (1997). When success breeds failure: The role of self-efficacy in escalating commitment to a losing course of action. Journal of Organizational Behavior, 18(5), 415-432. https://doi. org/10.1037/0021-9010.91.2.282 
DRUŠ. ISTRAŽ. ZAGREB STR. 599-619

GASHI TRESI, D., MIHELIČ, K. K.: GOING THE EXTRA... GOD. 29 (2020), BR. 4,

Whyte, G. (1998). Recasting Janis's groupthink model: The key role of collective efficacy in decision fiascoes. Organizational Behavior and Human Decision Processes, 73(2-3), 185-209. https://doi.org/10.1006/ obhd.1998.2761

Zimmerman, K. (2018, February 11). This is why millennial job seekers are so confident. Forbes. https://www.forbes.com/sites/kaytiezimmerman/2018/02/11/this-is-why-millennial-job-seekers-are-so-confident/ \#31b343561eb4

\section{Učiniti korak više: percipirana samoučinkovitost, obogaćivanje obiteljskih i radnih uloga, usmjerenost na promociju i odgovorno organizacijsko ponašanje}

Diellza GASHI TRESI

Riinvest College, Priština, Kosovo

Katarina Katja MIHELIČ

Sveučilište u Ljubljani, Ekonomski fakultet, Ljubljana, Slovenija

Polazeći od teorije kontrole, ovo istraživanje pridonosi boljem razumijevanju individualnih pretpostavki odgovornoga organizacijskog ponašanja zaposlenika. Cili je ispitati zajednički učinak triju pretpostavki - profesionalne samoučinkovitosti, obogaćivanja obiteljskih i radnih uloga te usmjerenosti na promociju - na odgovorno organizacijsko ponašanje u pružanju usluga. Na uzorku od 198 zaposlenika pozivnih centara upotrijebljena je metoda moderirane hijerarhijske regresije. Rezultati pokazuju krivolinijski odnos u obliku slova U između profesionalne samoučinkovitosti i odgovornoga organizaciijskog ponašanja u pružanju usluga kod zaposlenika $s$ iskustvom obogaćenih obiteljskih i radnih uloga. Nadalje, utvrđena je trosmierna interakcija profesionalne samoučinkovitosti, obogaćivanja obiteljskih i radnih uloga te usmierenja na promociju, kao zajedničkih prediktora odgovornoga organizacijskog ponašanja. U radu se na kraju iznose teorijske implikacije i praktični koraci namijenjeni poslodavcima koji žele poticati odgovorno organizacijsko ponašanje u svojim timovima, odjelima i organizacijama.

Ključne riječi: samoučinkovitost, obogaćivanje obiteljskih i radnih uloga, usmjerenost na promociju, odgovorno organizacijsko ponašanje

\section{(c) $(1) \Theta$}

Međunarodna licenca / International License: 